\title{
U I PERFORMANS MESIN PEMANEN DAN PERONTOK TYPE MOBIL COMBINE HARVESTER TERHADAP KEHILANGAN HASIL PADI
}

\author{
Emi Romansyah ${ }^{1 *}$, Nanang Wahyuddin², Nazaruddin ${ }^{3}$ \\ ${ }^{1}$ Teknik Pertanian, Universitas Muhammadiyah Mataram, erniroman@ummat.ac.id \\ ${ }^{2,3}$ Teknik Pertanian, Universitas Muhammadiyah Mataram
}

\section{INFO ARIIKEL}

RiwayatArtikel:

Diterima: 25-02-2018

Disetujui: 28-02-2018

\section{Kata Kunci:}

Mesin Pemanen

Perontok Padi

Combine Harvester

Kehilangan Hasil

\begin{abstract}
ABSTRAK
Abstrak: Kehilangan hasil selama panen dan perontokan merupakan beberapa masalah yang biasa dialami oleh para petani. Hal ini dapat terjadi karena kurangnya penerapan teknologi terhadap proses pemanenan dan perontokan Penelitian berjudul Uji Performansi Mesin Pemanen dan Perontok Type Mobil Combine Harvester Terhadap Kehilangan Hasil Padi. Tujuan penelitian ini adalah untuk mengetahui pengaruh cara pemanen dan perontok menggunakan alat Type Mobil Combine harvester terhadap kehilangan hasil padi dan mutu gabah. Metode yang digunakan dalam penelitian ini adalah metode eksperimental dengan pecobaan di Lapangan. Penelitian ini dirancang dengan menggunakan Rancangan Acak Kelompok (RAK) yang terdiri atas 3 perlakuan yaitu P1 = Alat "Gebot", P2 = Alat perontok Pedal Thresher, dan P3 = Alat perontok Combine Harvester. Parameter yang akan diamati dalam penelitian ini adalah meliputi susut perontokan (Spr), benda asing dan uji keratakan. Data hasil pengamatan dianalisis dengan analisis keragaman(Analysis of variance) pada taraf nyata $5 \%$. Bila ada perlakuan yang berpengaruh secara nyata maka diuji lanjut menggunakan uji Beda Nyata Jujur (BNJ) pada taraf nyata yang sama. Berdasarkan hasil penelitian dapat disimpulkan bahwa penggunaan mesin perontok padi berpengaruh nyata terhadap semua parameter susut perontok, \%, benda asing, dan \% uji keretakan. Mesin combine harvester memiliki nilai susut bobot, \%,benda asing, dan \% uji keretakan yang terendah dibandingkan dengan alat "gebot" dan pedal thresher.

Abstract: Loss of yield during harvest and threshing are some of the common problems experienced by farmers. This may occur due to the lack of application of technology to the harvesting and threshing process. Research titled is Performance Test of Harvesters and Thresher of Mobile Combine Harvester on Loss of Rice Yield. The purpose of research is to know the effect of harvesters and thresher using the Mobile Combine Harvester to the rice yield loss and grain quality. The research used experimental method, which designed using Completely Randomized Design (CRD) that consist of 3 treatments: P1 = "Gebot" Tool, P2 = Pedal Thresher, and P3 = Mobile Combine Harvester. Parameters to be observed in this research are covering thresher $(S P r)$, dirt and crack test. The observed data were analyzed by ANOVA (Analysis of variance) at 5\% level. If there is any treatment that has significant effect then tested continued using the test of (BNJ) on the same level. Based on the result of the research, it can be concluded that the use of rice thresher machine has significant effect on all shrinkage thresher, \%, dirt parameter and crack test\%. The harvester combine machine has a weight shrinkage value,\%, dirt, and \% crack test as compared with the "gebot" tool and the pedal thresher.
\end{abstract}

\section{A. LATAR BELAKANG}

Kebutuhan beras akan terus meningkat sejalan dengan meningkatnya tingkat kelahiran manusia di Indonesia. Dengan demikian maka diperlukan adanya peningkatan produksi beras. Dalam peningkatan produksinya, tidak hanya dilakukan dengan penambahan areal pertanaman padi tetapi juga dengan meminimalisasi susut atau loss yang terjadi saat panen atau pascapanen (Damardjati dan Purwani, 2011).

Kegiatan panen dan pascapanen padi meliputi beberapa proses yaitu pemanenan padi, penumpukan sementara padi, perontokan padi, pengangkutan padi, pengeringan gabah, penyimpanan gabah, dan kemungkinan adanya kehilangan hasil. Khususnya pada saat perontokan, banyak terjadi susut atau kehilangan gabah sehingga dapat mengurangi jumlah gabah. Gabah yang tercecer atau rontok umumnya akibat guncangan pada saat pemotongan batang padi. Penggunaan alat perotok alami merupakan salah satu masalah yang yang kini dihadapi petani, masalah utama adalah masih tingginya kehilangan hasil selama penanganan pasca panen yang besarnya sekitar $21 \%$. Kehilangan terbesar terjadi pada saat pemanenan sekitar 9\% dan pada tahap perontokan sekitar 5\% (Soemardi, 2012).

Kehilangan hasil selama panen dan perontokan merupakan beberapa masalah yang biasa dialami oleh para petani. Hal ini dapat terjadi karena 
kurangnya penerapan teknologi terhadap proses pemanenan dan perontokan (Rokhani, 2008).

Kehilangan hasil pada saat pascapanen padi dapat dipengaruhi oleh beberapa faktor, seperti umur panen, kadar air, varietas padi, serta alat perontokan yang digunakan (Setyono, 2006).

Pada masyarakat biasanya melakukan pemanenan dan perontokan padi menggunakan cara alami dan mesin, seperti alat "gebot", pedal thresher, power thresher, dan combine hervester. Adapun alat dan mesin yang digunakan dalam proses pemanen dan perontokan padi adalah mesin type mobil combine hervester. Pada umumnya, para petani menggunakan type mobil combine hervester untuk memanen dan merontokkan padi karena dianggap lebih mudah penggunaannya dan mengeluarkan biaya yang rendah. Selain itu, sebagai upaya untuk mempercepat modernisasi pertanian penggilingan gabah menjadi beras. Setiap proses kegiatan tersebut terdapat tersebut, mesin pemanen padi Combine harvester, bukan hanya memudahkan petani memanen padinya, tetapi dapat mengurangi kehilangan atau susut sehingga petani tidak banyak menanggung kerugian.

Cara kerja mesin ini juga cukup sederhana dan mudah dioperasikan. Tidak perlu banyak waktu untuk mempelajarinya. Tenaga yang dibutuhkan maksimal hanya tiga orang, satu operator/driver, dua orang lainnya bertugas mengatur pengemasan gabah. Dengan menggunakan Combine harvester ini, petani hanya butuh waktu 1-2 jam untuk memanen 1 ha padinya (Rokhani, 2008).

Petani tidak lagi mengeluarkan tenaga dan waktu ekstra untuk merontokkan bulir-bulir padi dari tangkainya. Sekali jalan, padi yang masih berdiri di hamparan sawah langsung terpisah dari tangkainya, dan langsung bisa dikemas. Damen atau pohon padi juga terpotong lembut. Keuntungan lain, mesin ini tidak boros bahan bakar. Untuk mengoperasikan alat bermesin diesel 45 PK ini, hanya dibutuhkan solar sebanyak 30 liter/ ha. Hanya saja, Combine harvester ini memiliki keterbatasan. Mesin ini akan sulit bekerja pada lahan dengan kedalam lumpur $20 \mathrm{~cm}$ atau lebih (Rokhani, 2008).

Dengan demikian diperlukan adanya suatu penghitungan mengenai besarnya penyusutan selama perontokan, penentuan alat dan mesin perontok yang mampu meminimalkan susut yang terjadi.

Berdasarkan uraian di atas maka akan dilakukan penelitian tentang Uji Performansi Mesin
Pemanen dan Perontok Type Mobil Combine Harvester Terhadap Kehilangan Hasil Padi.

\section{B. METODE PENELITIAN}

\section{Metode Penelitian}

Metode yang digunakan dalam penelitian ini adalah metode eksperimental dengan melakukan percobaan di lapangan.

\section{Rancangan Percobaan}

Rancangan percobaan yang digunakan dalam penelitian ini adalah Rancangan Acak Kelompok (RAK) dengan Alat perontokan (P) yang terdiri atas 3 perlakuan dan masing-masing perlakuan diulang 5 kali sehingga diperoleh 15 unit percobaan dengan rincian perlakuan sebagai berikut:

\section{$\mathrm{P} 1=$ Alat "Gebot" \\ P2 = Alat perontok Pedal Thresher (Hanafiah, 2005). \\ Waktu dan Tempat Penelitian Waktu Penelitian}

P3 = Alat perontok Combine Harvester

Data hasil pengamatan dianalisis dengan Analisis Keragaman (Analiysis of Variance) pada taraf nyata $5 \%$. Bila terdapat pengaruh beda nyata (signifikan) maka diuji lanjut menggunakan Uji Beda Nyata Jujur (BNJ) pada taraf nyata 5\%

Penelitian ini dilaksanakan Mulai Tanggal 2021 Bulan Mei 2017 di Desa Pakuan, Kecamatan Narmada, Kabupaten Lombok Barat.

\section{Bahan dan Alat Penelitian}

Adapun bahan yang digunakan dalam penelitian ini padi dan bahan bakar solar. Alat yang digunakan dalam penelitian ini meliputi mesin combine harvester, alat "gebot", alat perontok pedal thresher, terpal ukuran $8 \mathrm{~m} \times 8 \mathrm{~m}$ untuk alas pengamatan, Sabit, timbangan analitik, timbangan manual, wadah plastik, karung beras, penampi dan baki, mini husker satake rice machine, homogenizer sampel gabah dan beras, alat uji keretakan kiya seisakusho ltd, pinset, dan kaca pembesar.

\section{Pelaksanaan Penelitian}

Adapun tahapan-tahapan yang di persiapan dalam penelitian ini adalah melakukan observasi lahan, penyediaan dan pengecekan alat dan bahan, penyusunan matriks kerja, melakukan pengecekan terhadap umur padi mencapai 110-115 hari sesudah tanam, melakukan pengukuran terhadap petakan lahan yang akan di rontok masing-masing seluas 2,5m x 2m dengan berat kurang lebih $100 \mathrm{~kg}$. Selanjutnya penyabitan terhadap padi yang sudah di ukur petakan, melakukan pengamatan yaitu 
penimbangan terhadap padi yang sebelum dan sesudah di rontokkan.

\section{Parameter dan Cara Pengamatan Parameter}

Parameter yang akan diamati dalam penelitian ini adalah meliputi susut perontokan (Spr), benda asing dan uji keratakan.

\section{Cara Pengamatan}

Cara pengamatan dalam penelitian ini sebagai berikut:

\section{Susut Perontokan}

Susut perontokan adalah kehilangan hasil selama proses perontokan. Sebelum perontokan, padi varietas tertentu dan Adapun rumus yang digunakan dalam pemerolehan susut perontokan adalah sebagai berikut:

$$
\begin{aligned}
& S P r=\frac{\left(B T_{1}+B T_{2}+B T_{a}\right)}{\left(B T_{0}+B T_{1}+B T_{2}+B T_{2}\right)} \times 100 \% \\
& B T_{2}=\frac{B T_{2}(\text { sompel) }}{\text { Berat sompel jerami }(1 \mathrm{~kg})} x \text { Berat seluruh jermi }(\mathrm{kg})
\end{aligned}
$$

\section{Keterangan:}

SPr: Susut perontokan

T1 : Banyaknya butir gabah yang terlempar di luar alas petani tetapi masih di dalam alas pengamatan

T2 : Banyaknya butir gabah yang masih melekat pada jerami dan tidak terontok

T3 : Banyaknya butir gabah yang terbawa kotoran

BT0: Berat gabah hasil perontokan

BT1 : Berat gabah yang terlempar ke luar alas petani

BT2: Berat gabah yang masih melekat pada jerami dan tidak terontok

BT3 : Berat gabah yang terbawa kotoran

\section{Pemutuan Gabah}

Pemutuan gabah dilakukan dengan pengamatan terhadap kadar air GKP, gabah hampa, gabah bersih, benda asing, butir kuning/rusak, butir mengapur, butir hijau, butir merah, dan gabah varietas lain. Pemutuan gabah dilakukan pada pengkajian pengaruh alat/mesin perontok terhadap susut perontokan, dan pada pengkajian susut perontokan beberapa varietas padi.

Adapun pengamatan yang dilakukan yaitu:

\section{a. Kotoran dan Benda Asing}

Gabah sampel yang digunakan seberat 100 gram. Pemisahan dilakukan secara manual dengan menggunakan ayakan gabah, kaca pembesar, dan alat penjepit. Rumus yang digunakan sebagai berikut:

$$
\text { \%Benda asing }=\frac{\text { Benda Asing }(g)}{100 g} \times 100 \%
$$

\section{b. Uji Keretakan}

Pengamatan dengan mengambil 100 butir gabah dan dilakukan tiga kali sebagai pengulangan. Keretakan ini dapat dilihat dengan menggunakan alat uji keretakan.

\section{Analisis Data}

Data yang diperoleh akan dianalisa dengan bantuan alat Soft Ware Microsoft Exel, SPSS.

\section{Bagan Alir Pelaksanaan Penelitian}

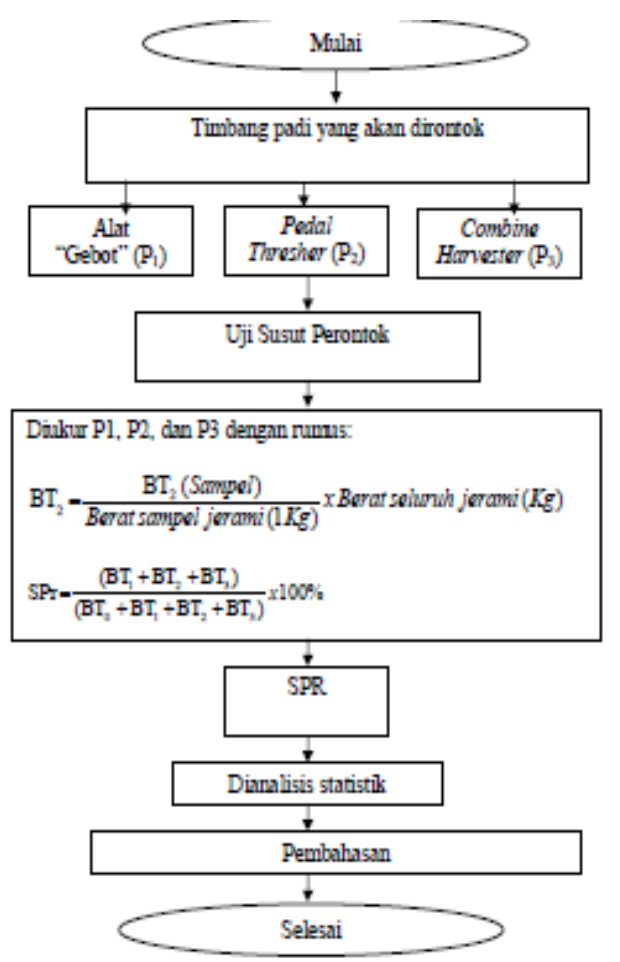

Gambar 1. Bagan Alir Analisis Uji Susut Perontok

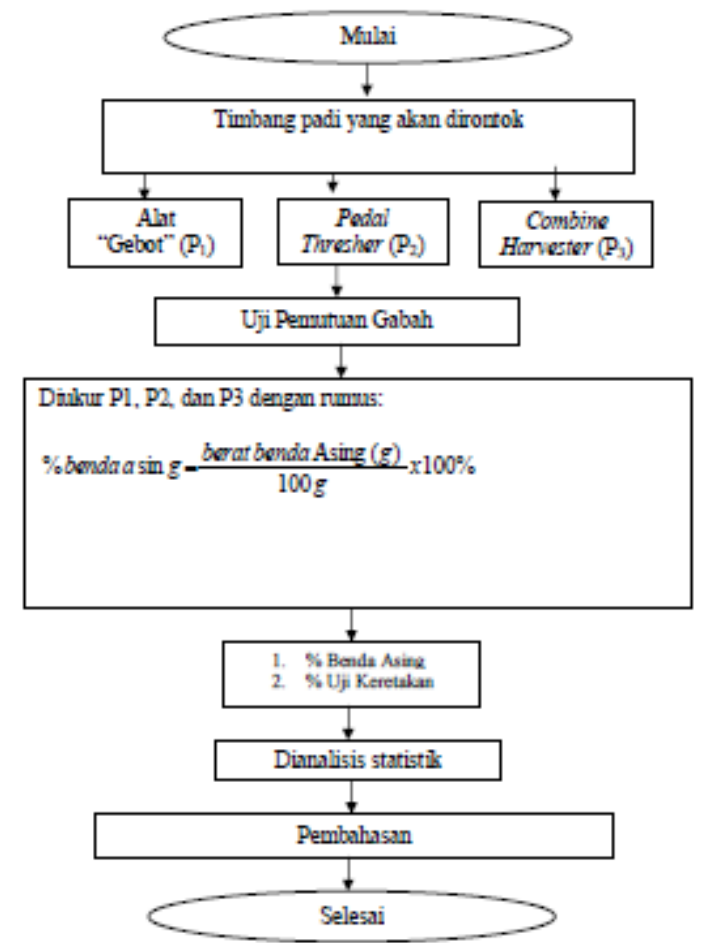

Gambar 2. Bagan Alir Analisis Uji Pemutuan Gabah 


\section{HASIL DAN PEMBAHASAN}

Data hasil penelitian dan analisis keragaman beserta hasil uji lanjut untuk parameter yang diamati disajikan pada Tabel 1 dan 2.

Tabel 1. Signifikansi Pengaruh Mesin Pemanen dan Perontok Terhadap Kehilangan Hasil Padi

\begin{tabular}{cccc}
\hline Parameter & $\mathrm{F}$ & $\mathrm{F}$ & Keterangan \\
& Hitung & Tabel & \\
\hline Susut Bobot & 11.87 & 3.48 & $\mathrm{~S}$ \\
\%Benda Asing & 5.81 & 3.48 & $\mathrm{~S}$ \\
\%Uji & 9.23 & 3.48 & $\mathrm{~S}$ \\
Keretakan & & & \\
\hline Keterangan : = Signifikan (Berpengaruh secara nyata)
\end{tabular}

Pada Tabel 1. Di atas menunjukan bahwa mesin pemanen dan perontok berpengaruh secara nyata terhadap semua parameter yaitu susut perontok, \%, benda asing, dan \% uji keretakan yang diamati, sehingga dilakukan uji lanjut dengan uji Beda Nyata Jujur (BNJ ) pada taraf nyata 5\% dapat dilihat pada Tabel 2.

Tabel 2 Purata Hasil Analisis Kualitas Alat Pemanen dan Perontok Terhadap Kehilangan Hasil Padi

\begin{tabular}{cccc}
\hline Perlakuan & $\begin{array}{c}\text { Susut } \\
\text { perontok }\end{array}$ & $\begin{array}{c}\text { \%Benda } \\
\text { Asing }\end{array}$ & $\begin{array}{c}\text { \%Uji } \\
\text { Keretakan }\end{array}$ \\
\hline Alat Gebot & $31.875 \mathrm{a}$ & $1,580 \mathrm{a}$ & $6.300 \mathrm{a}$ \\
Pedal & $27.427 \mathrm{~b}$ & $1,220 \mathrm{~b}$ & $4.000 \mathrm{~b}$ \\
Thresser & & & \\
Combine & $10.875 \mathrm{c}$ & 0,200 & $3.600 \mathrm{c}$ \\
Harvester & & $\mathrm{bc}$ & \\
BNJ & 0.696 & 0.102 & 0.867 \\
\hline
\end{tabular}

Keterangan : Angka-angka yang diikuti oleh huruf yang sama pada kolom yang sama tidak berbeda nyata pada taraf nyata $5 \%$.

Pada Tabel 2. kolom pertama (Susut Perontok) menunjukkan bahwa cara pemanen dan perontok menggunakan alat/ mesin pada perlakuan P1 berbeda nyata dengan perlakuan P2 da P3. Pada perlakuan P2 tidak berbeda nyata dengan perlakuan P1 dan P3. Pada perlakuan P3 berbeda nyata dengan perlakuan P1 dan P2.

Pada kolom kedua (\% Benda Asing) menunjukkan bahwa cara pemanen dan perontok menggunakan alat/mesin pada perlakuan P1 berbeda nyata dengan perlakuan P3 tetapi tidak berbeda nyata dengan perlakuan P2. Pada perlakuan P2 tidak berbeda nyata dengan perlakuan P1 tetapi tidak berbeda nyata dengan perlakuan P3. Pada perlakuan P3 berbeda nyata dengan perlakuan P1 tetapi tidak berbeda nyata dengan perlakuan $\mathrm{P} 2$.

Pada kolom ketiga (\% Uji Keretakan) menunjukkan

bahwa cara pemanen dan perontok menggunakan alat/mesin pada perlakuan P1 berbeda nyata dengan perlakuan P2 dan P3. Pada perlakuan P2 berbeda nyata dengan perlakuan P1 dan P3. Pada perlakuan P3 berbeda nyata dengan perlakuan P1 dan P2.

\section{Analisis Susut Perontok}

Mesin combine harvester memiliki nilai susut padi yang terendah yaitu 10,875\%. Sedangkan cara perontokan menggunakan pedal thresher mulai ditinggalkan karena kapasitas produksinya hampir sama dengan cara dibanting atau digebot (Herawati, 2008). Selain itu, petani mengalami kesulitan dalam penggunaan pedal thresher sehingga efisiensi waktu perontokan menjadi lebih rendah daripada alat "gebot".Untuk lebih jelasnya dapat dilihat pada Gambar 1.

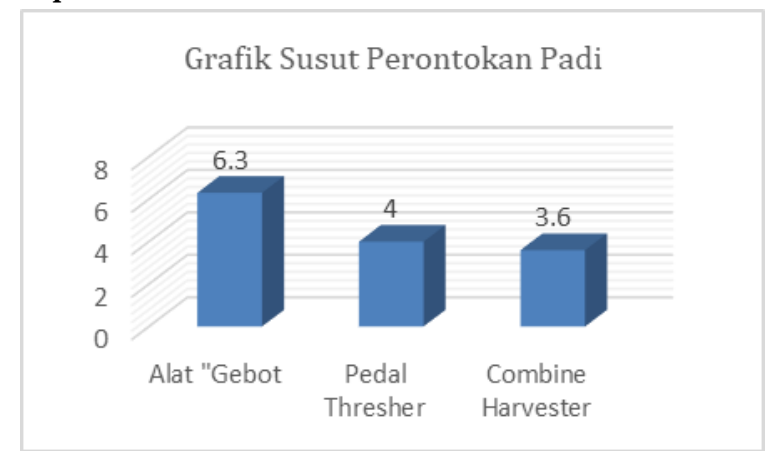

Gambar 3. Gtafik susut perontokan padi

Dalam pelaksanaan di lapangan, penggunaan pedal thresher masih belum optimal untuk dapat diaplikasikan terutama dengan keterkaitan perbandingan antara kemampuan serta daya kayuh alat.

\section{Analisis Benda Asing}

Perlakuan alat perontok memberikan pengaruh yang berbeda nyata terhadap mutu gabah. Sepeti terlihat pada Gambar 2 berikut.

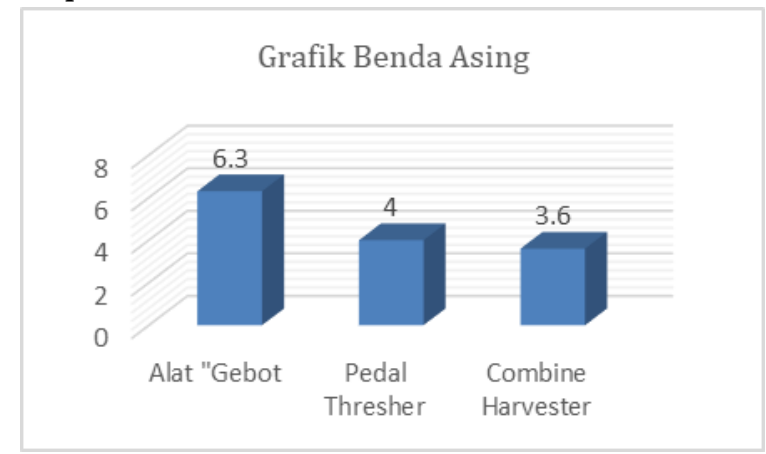

Gambar 4. Grafik benda asing

Persentase rata-rata benda asing dengan menggunakan alat gebot $(1,58)$ dan alat pedal thresher $(1,22)$ di bandingkan dengan alat combine harvester yang lebih rendah $(0,20)$. Rendahnya persentase benda asing menggunakan alat combine harvester dikarenakan mesin sudah di desain sedemikian rupa termasuk bagian penampung benda asing. 


\section{Analisis Keretakan}

Persentase rata-rata keretakan butiran gabah paling rendah adalah perontokan menggunakan combine harvester $(6,3 \%)$ dibandingkan dengan menggunakan alat "gebot" $(4,0 \%)$ dan pedal thresher $(3,6 \%)$. Perontokan menggunakan alat "Gebot" menyebabkan terjadinya kerusakan pada gabah berupa keretakan. Lebih lanjut dapat dilihat pada Gambar 3 berikut.

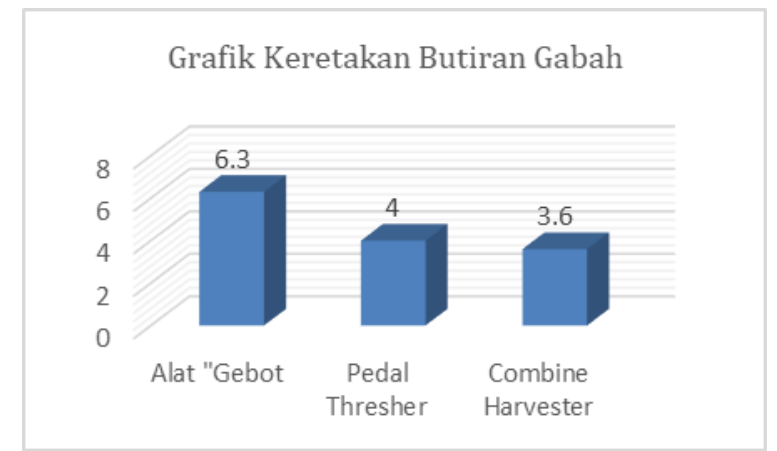

Gambar 5. Grafik Keretakan butiran gabah yang dirontokkan

Nilai persentase keretakan gabah paling rendah terdapat pada cara perontokan dengan menggunakan combine harvester, hal tersebut disebabkan karena alat tersebut merupakan alat yang praktis yang mempunyai tiga fungsi yakni memotong, merontokkan dan mengemaskan padi secara baik dan alat ini juga memiliki kemampuan merontokkan gabah dari tangkai atau batang secara langsung. Selain itu, mesin combine harvester memiliki silinder dengan kecapatan rendah sehingga mempengaruhi rendahnya nilai keretakan butiran gabah, semakin tinggi kecepatannya semakin tinggi pula keretakan gabah yang terjadi. Selain benturan dengan alat/mesin perontok, factor keretakan gabah dipengaruhi oleh karakteristik fisik, mutu, dan kandungan air dalam gabah (Sulistiadi, 2000).

\section{SIMPULAN DAN SARAN}

Berdasarkan hasil penelitian dan pembahasan yang terbatas pada ruang lingkup penelitian dapat disimpulkan hal-hal sebagai berikut :

1. Penggunaan mesin perontok padi berpengaruh nyata terhadap parameter susut perontok, \%, benda asing, dan \% uji keretakan.

2. Mesin combine harvester memiliki nilai susut padi, \%, benda asing, dan \% uji keretakan yang terendah dibandingkan dengan alat "gebot" dan pedal thresher.

3. Berdasarkan hasil penelitian dan analisis data bahwa perlakuan yang paling baik adalah P3 dengan perlakuan alat/mesin pemanen dan perontok menggunakan alat Type Mobil Combine harvester.

\section{DAFTAR RUJ UKAN}

Daftarrujukanditulisdengan font 9 pt, spasi 1.

\section{Buku}

[1] Damardjati, D.S., dan E. Y. Purwani. 2011. Mutu Beras. Dalam: Padi-Buku 3. Balai Penelitian dan Pengembangan Pertanian, Pusat Penelitian dan Pengembangan Tanaman. Bogor.

[2] Setyono, A. 2006. Teknologi Penanganan Pascapanen Padi. Balai Penelitian Tanaman Padi Sukamandi.

[3] Soemardi. 2012. Rendemen dan Kualitas dalam Pengolahan Padi. PT. Bhakti Pusat. Karawang.

\section{Artikel/Modul/Diktat}

[4] Rokhani, H. 2008. Susut Pascapanen: Lebih kepada Kendala Sosial. Artikel Susut Permasalahan Pascapanen Padi. http://www.ipb.ac.id/ [17 September 2008].

[5] Sulistiadi, Anis. 2000. Studi Perbandingan Perontokan Padi secara "Tles", "Banting", dan "Power Thresher" dengan Tenaga Penggerak 5 HP. Skripsi. Fakultas Mekanisasi dan Teknologi Hasil Pertanian. IPB. Bogor.

\section{Prosiding/Artikel Seminar}

[1] Herawati, Heni. 2008. Mekanisme dan Kinerja pada Sistem Perontokan Padi. Prosiding Seminar Nasional Teknik Pertanian 2008. Yogyakarta. 